\title{
A study on the speed of governments' healthcare response to COVID-19; cases: China, Hong Kong, Korea, Italy, the US, and Iran
}

Farshad Nourian

University of Tehran

Ahmad Sarabi ( $\sim$ ahmad.sarabii@yahoo.com )

University of Tehran https://orcid.org/0000-0003-0754-1558

S.Alireza Mousavinezhad

University of Tehran

\section{Research}

Keywords: Decision-making, Urban and social infrastructure, COVID-19 crises

Posted Date: October 14th, 2020

DOl: https://doi.org/10.21203/rs.3.rs-89161/v1

License: (c) (i) This work is licensed under a Creative Commons Attribution 4.0 International License.

Read Full License 


\section{Abstract \\ Background}

The spread of the novel COVID-19 virus has raised many questions on the performance of the national and global healthcare systems.

\section{Methods}

In this paper, we present the results of a study on how the decision-making speed at the national and city levels on dealing with the spread of the Corona virus has impacted the rate of mortality by means of Analytic Hierarchy Process (AHP) and Bubble chart.

\section{Results}

We considered variables such as the level of infrastructures in health, Information Technology, and human development in China and 5 other countries as all these factors could affect the rate of mortality in those countries as well. For each country, the data has been collected and analyzed starting with the time when the first patient was detected as a positive case up to three weeks later. For the time of decision-making, the data which could be used to illustrate the delay or promptitude of decisions included date of first death, date of quarantine, and the date of aviation suspension.

\section{Conclusion}

Our findings support the hypothesis that the timing of a government's decision, either proactive or preemptive, along with its level of sophistication in urban and social infrastructures, can impact the mortality rate of contagious diseases such as COVID-19.

\section{Introduction}

The 21 century has witnessed three major coronavirus epidemics thus far; with the third one, COVID-19, turning into a pandemic. A handful of national governments in countries, such as South Korea and Taiwan, used the "lessons learned" from the two previous epidemics to prepare for similar crisis. Many others, such as Iran and the United States did not bother to plan for these days. And there are many among citizens who are seriously questioning governments' inaction. In this paper, we present the results of a research on how the speed of decision making at the national level, the countries' health infrastructures and social structures have affected the mortality caused by the latest pandemic in a case study of 6 countries. 
The first infectious disease of the 21st century was the Sever Acute Respiratory Syndrome (SARS). It turned into an epidemic in 2002. Its consequences included social and economic disruptions. International trade and tourism were greatly affected, streets in many cities were deserted, and public health systems were crippled $[86,87]$. Nonmedical public health interventions were employed to contain the epidemic. These included closing schools, forbidding mass gatherings, limiting international travel and screening travelers at borders, finding and isolating those who were infected, and quarantining the related ones by means of contact tracing. By 2003, SARS had spread to 29 countries, infected 8,098 people, and killed 774 of them [88].

The second deadly epidemic disease was the Middle East Respiratory Syndrome (MERS); first reported in Saudi Arabia in 2012 [89]. As in SARS, the virus transmitted among people through close contact, affecting the respiratory system. The common symptoms included severe shortness of breath, fever, and cough. The failure of the Saudi Arabian government's rapid response increased the number of infected patients over time. As of March 2020, 2,521 MERS cases were confirmed globally with 866 deaths due to the illness, mainly in Saudi Arabia.

On January 7, 2020, Chinese authorities confirmed that they had identified a novel coronavirus as the cause of the pneumonia [2] [3]. On March 11, 2020 the World Health Organization (WHO) declared the outbreak of the coronavirus a pandemic, which it defines as "global spread of a new disease". WHO chose the COVID-19 for the name of the disease. At the time of this writing, the virus has spread rapidly around the world, affecting more than 202 countries and territories, infecting over three million and killing more than 240,000 people.

The past 4 months have shown differences between decision time and clock time [1]. The virus has created severe threat for public health and global and local economies [5]. COVID-19 is transmitted from human-to-human; and therefore, authorities in national governments have employed nonmedical public health interventions as in SARS and MERS, mentioned above (for a list of current interventions refer to [6] and [7]).

WHO has also drafted a response plan and strategies for global actions and authorities are advised to take action in line with those strategies. In most countries, governments have implemented similar protocols. The results, however, are not the same in terms of mortality and number of infected citizens. Furthermore, in crisis planning, decision making and management, there is a need to decrease discomfort to citizens while increasing effectiveness of interventions since those affected and their families are not just numbers in statistics $[8,9,10]$.

In this paper, we look at how the differences in speed of decision making in response to the spread of COVID-19 in different countries, along their level of IT and smart infrastructures, income levels, and healthcare infrastructures have thus far affected the rate of mortality in those countries.

\section{Related work}


Governments adopted a number of different approaches to cope with SARS and MERS, in 2002 and 2012 respectively. The past experiences from those outbreaks could have been used to prepare for the next one. Specifically, the world's public health system was tested for its capacity to respond rapidly and decisively. For example, the MERS outbreak was exacerbated by inappropriate responses by major institutions in many countries [92]. National and local governments failed to deliver timely information about the status of the epidemic and response procedures related to MERS.

Thus, preparedness could be analyzed within the realm of governments' decision making processes. There are a variety of factors that influence decision-making at the national and local levels, in line with strategic thinking [16], on how to intervene to stop the spread of the virus. Glasser et al. [90] argue that the factors which contribute to containment include reduction "in time from symptom onset to clinical presentation and diagnosis during the course of [the] outbreak, together with increasingly effective isolation and other infection-control procedures". Thus, increased speed in decision making can lead to shortening intervals between the onset of clinical symptoms and isolation of patients with coronavirus and this, in turn, reduces the extent of transmission.

The literature on previous attempts to deal with the COVID-19 includes a review of the role of information dissemination and IT infrastructure as well. Yang and Cho [91], point out that when reliable information is lacking, people incline toward rumors and tend to believe inaccurate information from social media and the internet. This increases the level of perceived risk and public distrust of governments which, in turn, makes the healthcare decisions and efforts less effective. Pan et al. [93], also point to Singapore's successful intervention in containment of the SARS outbreak which included "streamlined communications, information exchange, and data flow, and significantly eased collaboration among government agencies, private businesses, foreign agencies, and the public". The idea was to optimize leadership, speed, and coordination by keeping the public up-to-date and helping both public and private sectors to respond to crisis situations.

Furthermore, public participation in cities could play considerable role in increased efficiency of local governmental decisions [17]. Administrators and decision makers at municipalities have implemented different methods and tools to inform their communities, such as social networks [18], online methods based on artificial intelligence [19], and through devices used in smart cities [13] [11].

Risk communication is referred to as an action of "exchanging information about health and/or environments between interested parties" [94]. Such information includes the factors of health and environment risk itself and policy decisions for controlling and managing those risks. In this respect, it is accepted that Coronavirus is a global crisis [5]; and therefore, it needs a global crisis management based on substantive rationality, in which not only national but also international threats are considered in preemptive and reactive decisions [9]. Healthcare officials at the national levels should be empowered to make globally accepted decisions $[22,95]$.

In the following sections, the concepts and variables mentioned above are discussed in detail within a quantitative methodology to better understand the impacts of decision makers' approach toward COVID- 


\section{Methodology}

Strategic decision-making practices can impact the health of society and, in a pandemic, may be crucial in controlling the mortality rate. Thus, in this paper, we present the results of a research on how the speed of decision making at the national and local level has affected the mortality caused by the novel COVID19. For this purpose, in our research, we have used a multiple-case study approach and multi-criteria analysis to look at the decisions made by governments in confronting the pandemic.

\section{a) Case selection}

A total of six countries are selected as our cases in this study. Here, China is considered as the benchmark of our analysis because it was the first country in the world which announced the COVID-19 outbreak within its borders [27]. In order to choose the other cases for our study, we focused on a logical strategy which could help us to draw conclusions based on rational reasoning [24]. Therefore, five countries were chosen with differences in time of their first death, location, population and infrastructure. Four cases contain the most infected people in their region according to the World Health Organization (WHO) situation reports [28]. The sixth country is chosen here because of its proximity to the City of Wuhan where the outbreak apparently began.

In WHO's $60^{\text {th }}$ situation report [29], Republic of Korea contains the most total confirmed COVID-19 cases in the Western Pacific Region after China. Among the European countries, Italy is at the top of the list of mortalities and has the most total confirmed case of COVID-19 thus far. Our next case is Iran, located in the Eastern Mediterranean Region. Iran's total confirmed cases are more than any other country in the region. In the Americas, the United States has the largest number of total confirmed cases and mortality. We also decided to select Hong Kong since it holds Chinese nationals while maintaining separate governing and economic systems from that of mainland China [30].

\section{(b) Data collection and analysis}

In our research design, the main source of data on the latest pandemic is WHO's website which contains both rich and official data on all countries. For the other criteria in our analysis, we collected data from the official sites of governments and other published peer-reviewed papers. The collected data covered the six domains which together impact the decision-making in each country and their statistics in regard to mortality from the virus: 1) number of total confirmed cases, 2) number of total deaths, 3) population, 4) decision-making time, 5) infrastructures 6) human development. The time-span for the data used here is from 21 January to 20 March of 2020. For each country, however, the data from the first death up to three weeks has been collected and analyzed beginning with the time when the symptoms showed and the first patient in that country was detected as positive [31] in order to achieve an equal judgment in our comparison between the countries. 
To begin the data analysis according to the research design, a detailed description of each case was created and the appropriate information compatible with the objectives of this study were gathered. The latest United Nations Population Division data is also used for collecting data on each country's population [32] [33]. Next, we needed data on the three main criteria used here for the comparison purposes. For the time of decision-making, the data which could be used to illustrate the delay or promptitude of decisions include: date of first death, date of quarantine, and the date of aviation suspension. Then, we reviewed journal papers and official sites to determine each country's level of infrastructure in terms of (a) Information Technology and smart cities and (b) healthcare system [35] [36]. Finally, we needed to look at the economic condition and knowledge level of society in each country in order to gain an understanding of the social standing of our cases. We used the Human Development Index (HDI) for this criteria. The HDI reflects social structure, health and welfare, level of knowledge, and the overall quality of life [38].

In general, we used both quantitative and qualitative data. For the latter, expert judgement was used for analysis. The analytic hierarchy process (AHP) [67] has been employed as the most suitable method to analyze both qualitative and quantitative information [68]. In order to create a better visual understanding of the interconnections across domains of research, cases are shown in Fig 2. Also, the characteristics across the three factors which are involved in the decision-making in our cases - urban and social infrastructure, reaction promptness and proportion of mortality to the total infected population - is discussed in the finding section below.

\section{Results}

Table 1 presents a view of the countries and the related variables. As discussed above, the cases are from different regions of the world. All have faced the COVID-19 outbreak and have used different strategies to contain it. As mentioned, China is our benchmark of the contagion. This country has a population of about 1.5 billion people, followed by the United States with near 330 million people. Hong Kong, has the lowest population among our cases with 7.5 million people.

The recent literature points to the fact that the novel virus affects the older members of society more than the young. Thus, the median age shown in the table, which divides the population into two numerically equally sized groups, could have an effect on the results [39] [6].

The numbers of total confirmed infected persons and deaths are critical here since this numbers indicates how far the decisions for containment of the pandemic have affected the societies in each country. All the confirmed cases were counted from the date of first death in each country up to three weeks later.

China's first death was reported on February 2, 2020. In its first three weeks after that, the highest number of infected cases and deaths were reported by 14411 and 304 respectively. [40]. Soon after, other countries began to report the spread of the virus. Italy has the highest rate of deaths in Europe. In the first three weeks period, 1268 people died of COVID-19 which is higher than China in the same period [41]. Iran 
and the United States are ranked as the third and fourth place of deaths respectively [42] [32]. Republic of Korea has reported 7979 total infected case and 66 total deaths [29]. Hong Kong has the lowest confirmed case (81) during the first three weeks [43].

Table 1

An overview of case countries

\begin{tabular}{|c|c|c|c|c|c|}
\hline Country & Territory & Population & $\begin{array}{l}\text { Med. } \\
\text { Age }\end{array}$ & $\begin{array}{l}\text { Total Confirmed } \\
\text { Case ( } 3 \text { weeks) }\end{array}$ & $\begin{array}{l}\text { Total } \\
\text { deaths ( } 3 \\
\text { weeks) }\end{array}$ \\
\hline China & $\begin{array}{l}\text { Western Pacific } \\
\text { Region }\end{array}$ & $1,439,323,776$ & 38 & 14411 & 304 \\
\hline $\begin{array}{l}\text { Republic of } \\
\text { Korea }\end{array}$ & $\begin{array}{l}\text { Western Pacific } \\
\text { Region }\end{array}$ & $51,269,185$ & 44 & 7979 & 66 \\
\hline Italy & European region & $60,461,826$ & 47 & 17660 & 1268 \\
\hline $\begin{array}{l}\text { Iran (Islamic } \\
\text { Republic of) }\end{array}$ & $\begin{array}{l}\text { Eastern } \\
\text { Mediterranean } \\
\text { Region }\end{array}$ & $83,992,949$ & 32 & 9000 & 354 \\
\hline $\begin{array}{l}\text { United States of } \\
\text { America }\end{array}$ & $\begin{array}{l}\text { Region of the } \\
\text { Americas }\end{array}$ & $331,002,651$ & 38 & 10442 & 150 \\
\hline Hong Kong & $\begin{array}{l}\text { Western Pacific } \\
\text { Region }\end{array}$ & $7,496,981$ & 45 & 81 & 2 \\
\hline
\end{tabular}

In Table 2, the three main criteria of our research are shown. We call the first criteria as "decision-making speed". This is the time span in which all countries announced their first death: from 11 January to 29 February 29. As shown, in China, the first death was reported in 11 January [44]; this date in Republic of Korea was 21 February [45]; and in Italy it was 22 February [46]. The first reported death in Iran and the United States were February 20th and 29th respectively $[20,47]$. The date of the first reported death in Hong Kong was February 4, 2020 [49].

Time of quarantining is also important because the delay in quarantining leads to faster virus spread. It can also indicate the hesitation in a country's decision-making process [50]. In China, quarantine was enforced for Wuhan with a population of 11 million people on 22 January [44] [51]. In Italy, however, the government implemented national quarantine almost one month later, on 21 February of 2020 [52] [53]. Iran, instead of quarantine, called for social distancing and self-isolation. The dates in which the countries suspended airline activities are shown in the next column as well.

The second criteria is shown in Table 2 is infrastructure. Two types of infrastructure are important here: Information Technology (IT) and healthcare. We categorized our sample countries into developed, developing, and underdeveloped based on their level of infrastructure in these two aspects. As discussed in the previous sections, smart cities provide a context for IT related activities. In this paper, it is not our intention and there is no room for a detailed discussion on the concept of smart cities, their requirements and their benefits to the citizens and the healthcare system in detail. It suffices here, however, to assume 
that those countries with greater number of smart cities have a better infrastructure for certain activities such as more extensive use of social networks, more efficient exchange of information about health between interested parties, and working from home. Thus, for the comparison purposes, we used the number of smart cities as a novel measure of IT infrastructure in our sample countries.

Furthermore, on healthcare infrastructure, we looked at the health care system's capabilities using Global Health Security index (GHS) [61]. This index scores and ranks countries' health security across six categories, 34 indicators and 85 sub-indicators and could show the amount of risk impact on various national health. According to this data, the United States and Republic of Korea are the most prepared countries in health security. Iran is ranked lowest in the list of our sample countries. It should be noted that Hong Kong, as part of China, is not included in the GHS Index as a country [62].

Our third criteria is social structure. The Human Development Index (HDI) is used here to compare our sample countries on indices such as Income [63], level of education [64] and life expectancy of citizens [65]. As shown in the Table 2, Hong Kong is ranked the highest in HDI index, followed by the United States and Republic of Korea.

Table 2 Comparison of countries using the three main criteria

\begin{tabular}{|c|c|c|c|c|c|c|}
\hline \multirow[b]{2}{*}{ Country } & \multicolumn{3}{|c|}{ First Criteria : Decision Making Speed } & \multicolumn{2}{|c|}{ Second Criteria: Infrastructure } & \multirow{2}{*}{$\begin{array}{c}\text { Third Criteria: Social } \\
\text { Structure } \\
\begin{array}{c}\text { Human Development } \\
\text { Index }\end{array}\end{array}$} \\
\hline & $\begin{array}{c}\text { First Reported } \\
\text { Death (Date) }\end{array}$ & $\begin{array}{l}\text { Quarantine } \\
\text { (Date) }\end{array}$ & $\begin{array}{l}\text { Airlines Suspend } \\
\text { Flights (Date) }\end{array}$ & $\begin{array}{l}\text { (Number of smart } \\
\text { cities in top 50) }\end{array}$ & $\begin{array}{c}\text { GHS Index } \\
\text { (Rank - Score) }\end{array}$ & \\
\hline China & 11-Jan & 22-Jan & No restrict & 3 & 51 th -48.2 & 85 th -0.758 \\
\hline Republic of Korea & 20-Feb & Self-isolation & 4-Feb & 1 & 9th -70.2 & $22 n d-0.906$ \\
\hline Italy & 22-Feb & 21-Feb & 31-Jan & 0 & 31th -56.2 & 29 th -0.883 \\
\hline Iran (Islamic Republic of) & 19-Feb & - & 27-Feb & 0 & 97 th -37.7 & 65th -0.797 \\
\hline United States of America & 28-Feb & 24-Mar & 31-Jan & 12 & 1st -83.5 & 15th -0.920 \\
\hline Hong Kong & 4-Feb & 23-Jan & 28-Jan & 1 (Hong Kong) & No Data & 4th -0.939 \\
\hline & & & & meor & $\begin{array}{l}\text { Most prepared } \\
\text { More prepared }\end{array}$ & $\begin{array}{c}\text { best } \\
\text { upper med }\end{array}$ \\
\hline & & & & best & Least prepared & med \\
\hline
\end{tabular}

\section{Discussion And Findings}

The variables used in this research are discussed and the findings are presented below:

First, the decisions at the national and local governments in regard to limiting the activities of the population during the pandemic are related to the number of people infected and the number of deaths. Obviously, it is not possible for any country to test all citizens for COVID-19 infection. Therefore, in this research, instead of using the proportion of mortality to the population of each country, we used the 
proportion of mortality to the confirmed cases by each nation (Fig. 1). In Fig. 2, the size of each bubble demonstrates the extent of the proportion in each country in our sample. Here, Italy and Iran have the highest proportion with 7.18 and 3.93 percent over the first three weeks period after the first reported death, respectively. The Republic of Korea has the lowest proportion (under 1 percent). The United States, despite having the best healthcare infrastructure (as shown in Table 1), is second to Korea. Both China and Hong Kong have about 2 percent of mortality to the confirmed cases. The reason for the Republic of Korea's success during the first three weeks could be attributed to its government's strategic decisions in response to COVID-19 outbreak as well as its infrastructures.

In the first three weeks of the COVID-19 crisis, countries' decision making time to take action against the spread of virus differed. WHO had warned governments that movement restrictions may be ineffective and could only hurt the economies of the countries unless such restrictions are enforced in the very early days after the first infected person is identified. [75]. That is the case for other decisions such as social distancing and quarantining of persons as well [76]. Therefore, timing is vital to overcome the spread of the disease.

In this regard, governments also suspended flights to and from China [77] [78]. Some countries, such as Iran and the United States, however, delayed the implementation of this decision for a few weeks. In the Republic of Korea, not only self-isolation was implemented, movements of many of the infected people were traced and those whom had come to contact with them were quarantined [79]. This was either ignored or weakly implemented in the other countries. In Italy, despite huge numbers of deaths per day, the government took its time to quarantine the entire country [80]. On the other hand, Hong Kong had proactively implemented travel restrictions on passengers coming from the mainland and designated the Lady MacLehose Holiday Village in Sai Kung as a quarantine center immediately [81] [82]. In Fig. 2, the mortality rate as a dependent variable to decision time by the sample countries is shown between preemptive and permissive actions, relative to their level of infrastructure from weak to strong, using the AHP analysis.

\section{Conclusion}

This study demonstrated that a correlation exists between the authorities' decision time, as well as the social and IT infrastructures and the mortality rate in our cases during the COVID-19 crisis. As shown in the bubble chart (Fig. 2), those countries with bigger bubbles are placed near to the lower left corner. These countries, which have weaker IT and healthcare infrastructure, have made a more permissive decision. The countries located in this area of the chart, are Iran and Italy. Both countries have bigger bubbles than other cases. It should be noted that the bubble for Iran is smaller than that of Italy but is located well in the lower left corner. This contradiction may be due to the possibility that the statistics released by each country on the number of infected and/or the deaths are not accurate. Another important factor could be the median age as mentioned in previous sections. The Italian population is much older than the Iranian one which could account for the considerable difference in the mortality rate. On the opposite, the United States, which according to the HDI and GHS data as well as the number of 
smart cities has the best urban and social infrastructure among our sample, seems to have been in a better position in the first three weeks to deal with this pandemic. Its bubble along with the Republic of Korea is the smaller than the other countries. The government of Korea, geographically located near China, has made preemptive decisions in this regard. Despite the fact that Hong Kong has the high proportion of mortality to the number of infected people in the first three weeks, its healthcare infrastructures are well developed as compared to other sample countries.

Finally, our findings support the assumption that the timing of a government's decision, being proactive or preemptive, in the decisions along with its level of sophistication in urban and social infrastructures, can impact the mortality in contagious diseases such as COVID-19. As shown in the chart, there are two areas that are separated with arcs. These are located in the corners and depict the manageability; meaning that, by moving from permissive decision to preemptive one and from weak infrastructure to strong, the fight with this pandemic would be more manageable for authorities in a given country. The chart could be used as a hierarchical chart for predicting the risk of death and the spread of infection among citizens, especially for those countries in which COVID-19 is not serious yet and for the future pandemics.

\section{Declarations}

- Ethics approval and consent to participate: Not applicable.

- Consent for publication: Not applicable.

- Availability of data and materials: All data generated or analyzed during this study are included in this published article.

- Competing interests: The authors declare that they have no competing interests.

- Funding: Not applicable.

- Authors' contributions: F.N, A.S, and S.A.M contributed to the design and implementation of the research, to the analysis of the results and to the writing of the manuscript.

- Acknowledgements: Not applicable.

\section{References}

1. Rosenthal, U. and P.t. Hart, Experts and decision makers in crisis situations. Knowledge, 1991. 12(4): p. 350-372.

2. Lu, H., C.W. Stratton, and Y.W. Tang, Outbreak of Pneumonia of Unknown Etiology in Wuhan China: the Mystery and the Miracle. Journal of Medical Virology.

3. Organization, W.H., WHO Director-General's remarks at the media briefing on 2019-nCoV on 11 February 2020. 2020. 2020.

4. Organization, W.H., Coronavirus disease 2019 (COVID-19): situation report, 75. 2020.

5. Wu, J.T., K. Leung, and G.M. Leung, Nowcasting and forecasting the potential domestic and international spread of the 2019-nCoV outbreak originating in Wuhan, China: a modelling study. The 
Lancet, 2020. 395(10225): p. 689-697.

6. Stein, R., COVID-19 and Rationally Layered Social Distancing. International Journal of Clinical Practice, 2020: p. e13501.

7. Sohrabi, C., et al., World Health Organization declares global emergency: A review of the 2019 novel coronavirus (COVID-19). International Journal of Surgery, 2020.

8. Hough, M.G. and J.E. Spillan, Crisis planning: Increasing effectiveness, decreasing discomfort. Journal of Business \& Economics Research (JBER), 2005. 3(4).

9. Rosenthal, U. and A. Kouzmin, Crises and crisis management: Toward comprehensive government decision making. Journal of Public Administration Research and Theory, 1997. 7(2): p. $277-304$.

10. Williams, W.V., J. Lee, and P.R. Polak, Crisis intervention: Effects of crisis intervention on family survivors of sudden death situations. Community mental health journal, 1976. 12(2): p. 128-136.

11. Robbins, M.D., B. Simonsen, and B. Feldman, Citizens and resource allocation: Improving decision making with interactive web-based citizen participation. Public Administration Review, 2008. 68(3): p. 564-575.

12. Church, J., et al., Citizen participation in health decision-making: past experience and future prospects. Journal of Public Health Policy, 2002. 23(1): p. 12-32.

13. Kingston, R., Public participation in local policy decision-making: the role of web-based mapping. The Cartographic Journal, 2007. 44(2): p. 138-144.

14. Hopman, J., B. Allegranzi, and S. Mehtar, Managing COVID-19 in low-and middle-income countries. JAMA, 2020.

15. Gostin, L.O., Public Health Emergency Preparedness: Globalizing Risk, Localizing Threats. JAMA, 2018. 320(17): p. 1743-1744.

16. Steptoe-Warren, G., D. Howat, and I. Hume, Strategic thinking and decision making: literature review. Journal of Strategy and Management, 2011.

17. Thomas, J.C., Public involvement and governmental effectiveness: a decision-making model for public managers. Administration \& society, 1993. 24(4): p. 444-469.

18. Rapid outbreak response requires trust. Nature Microbiology, 2020. 5(2): p. 227-228.

19. Rao, A.S.S. and J.A. Vazquez, Identification of COVID-19 Can be Quicker through Artificial Intelligence framework using a Mobile Phone-Based Survey in the Populations when Cities/Towns Are Under Quarantine. Infection Control \& Hospital Epidemiology, 2020: p. 1-18.

20. Eweje, J., R. Turner, and R. Müller, Maximizing strategic value from megaprojects: The influence of information-feed on decision-making by the project manager. International Journal of Project Management, 2012. 30(6): p. 639-651.

21. Bonnafous-Boucher, M. and S. Porcher, Towards a stakeholder society: Stakeholder theory vs theory of civil society. European Management Review, 2010. 7(4): p. 205-216.

22. Hagbaghery, M.A., M. Salsali, and F. Ahmadi, The factors facilitating and inhibiting effective clinical decision-making in nursing: a qualitative study. BMC nursing, 2004. 3(1): p. 2. 
23. Yin, R.K., Case study research and applications: Design and methods. 2017: Sage publications.

24. Cicmil, S., et al., Rethinking project management: researching the actuality of projects. International journal of project management, 2006. 24(8): p. 675-686.

25. Siskos, E., D. Askounis, and J. Psarras, Multicriteria decision support for global e-government evaluation. Omega, 2014. 46: p. 51-63.

26. Tran Thi Hoang, G., L. Dupont, and M. Camargo, Application of Decision-Making Methods in Smart City Projects: A Systematic Literature Review. Smart Cities, 2019. 2(3): p. 433-452.

27. Li, Q., et al., Early transmission dynamics in Wuhan, China, of novel coronavirus-infected pneumonia. New England Journal of Medicine, 2020.

28. Who.int., Novel Coronavirus (2019-Ncov) Situation Reports. 2020.

29. Organization, W.H., Coronavirus disease 2019 (COVID-19): situation report, 53. 2020.

30. Hklii.hk. Instrument A301 Joint Declaration Of The Government Of The United Kingdom Of Great Britain And Northern Ireland And The Government Of The People's Republic Of China On The Question Of Hong Kong Joint Declaration. 2020 [cited 20201 April]; Available from: https://www.hklii.hk/eng/hk/legis/instrument/A301/declaration.html.

31. Dorigatti, I., et al., Report 4: severity of 2019-novel coronavirus (nCoV). Imperial College London, London, 2020.

32. Organization, W.H., Coronavirus disease 2019 (COVID-19): situation report, 60. 2020.

33. Worldometers.info. Population By Country (2020) - Worldometer. 2020 [cited 20201 April ]; Available from: https://www.worldometers.info/world-population/population-by-country/.

34. Robert Baum, J. and S. Wally, Strategic decision speed and firm performance. Strategic management journal, 2003. 24(11): p. 1107-1129.

35. school, I.b. Smart City Index. 2020 [cited 20201 April]; Available from: https://www.imd.org/smartcity-observatory/smart-city-index/.

36. Index, G. The Global Health Security Index. 2020 [cited 20201 April]; Available from: https://www.ghsindex.org/.

37. Shan Jie , L.Q. Smart city projects help China contain coronavirus. 2020 [cited 20201 April]; Available from: https://www.globaltimes.cn/content/1179737.shtml\#.XknfhZplG-s.linkedin.

38. Hdr.undp.org. Human Development Index (HDI). [Online] 2020 [cited 20201 April]; Available from: http://hdr.undp.org/en/content/human-development-index-hdi.

39. Wang, D., Hu, B., Hu, C., Zhu, F., Liu, X., Zhang, J., Wang, B., Xiang, H., Cheng, Z., Xiong, Y. and Zhao, Y., Clinical characteristics of 138 hospitalized patients with 2019 novel coronavirus-infected pneumonia in Wuhan, China. Jama, 2020.

40. Organization, W.H., Coronavirus disease 2019 (COVID-19): situation report, 13. 2020.

41. Organization, W.H., Coronavirus disease 2019 (COVID-19): situation report, 54. 2020.

42. Organization, W.H., Coronavirus disease 2019 (COVID-19): situation report, 52. 2020.

43. Organization, W.H., Coronavirus disease 2019 (COVID-19): situation report, 36. 2020. 
44. Organization, W.H., Coronavirus disease 2019 (COVID-19): situation report, 1. 2020.

45. Organization, W.H., Coronavirus disease 2019 (COVID-19): situation report, 32. 2020.

46. Organization, W.H., Coronavirus disease 2019 (COVID-19): situation report, 33. 2020.

47. Organization, W.H., Coronavirus disease 2019 (COVID-19): situation report, 31. 2020.

48. Organization, W.H., Coronavirus disease 2019 (COVID-19): situation report, 40. 2020.

49. Organization, W.H., Coronavirus disease 2019 (COVID-19): situation report, 15. 2020.

50. Boni, M.F., et al., Virulence attenuation during an influenza A/H5N1 pandemic. Philosophical Transactions of the Royal Society B: Biological Sciences, 2013. 368(1614): p. 20120207.

51. Juliana Kaplan, L.F., Morgan McFall-Johnsen. A third of the global population is on coronavirus lockdown - here's our constantly updated list of countries and restrictions. [Online] 202010 April [cited 20201 April]; Available from: https://www.businessinsider.com/countries-on-lockdowncoronavirus-italy-2020-3.

52. Aljazeera.com. Coronavirus: Travel Restrictions, Border Shutdowns By Country. [Online] 2020 [cited 20201 April]; Available from: https://www.aljazeera.com/news/2020/03/coronavirus-travelrestrictions-border-shutdowns-country-200318091505922.html?xif=.

53. Nytimes.com. As New Cases Surge, Businesses Face Grim Fallout. [Online] [cited 20201 April]; Available from: https://www.nytimes.com/2020/02/21/world/asia/china-coronavirus.html\#linkfc87a29.

54. Chivukula, K. Coronavirus: Italy and Israel ban all flights from China. [Online] 2020 [cited 20201 April]; Available from: https://www.aerospace-technology.com/news/italy-israel-ban-flights-china/.

55. SchengenVisalnfo.com. Italy Suspends Visa Issuance and All Air Traffic From China. [Online] 2020 [cited 20201 April]; Available from: https://www.schengenvisainfo.com/news/italy-suspends-visaissuance-and-all-air-traffic-from-china/.

56. Alex Leary, B.A. U.S. Imposes Entry Restrictions Over Coronavirus. [Online] 2020 [cited 2020 1April].

57. Security, D.o.H. Fact Sheet: DHS Notice of Arrival Restrictions on China, Iran and Certain Countries of Europe. [Online] 2020 [cited 20208 April]; Available from:

https://www.dhs.gov/news/2020/03/17/fact-sheet-dhs-notice-arrival-restrictions-china-iran-andcertain-countries-europe.

58. Italy, U.S.E.C.i. COVID-19 Information / U.S. Embassy \& Consulates In Italy. [Online] 2020 [cited 20208 April]; Available from: https://it.usembassy.gov/COVID-19-information/.

59. News.rthk.hk. Visitor Becomes First To Be Quarantined Over Virus. [Online] 2020 [cited 20208 April]; Available from: https://news.rthk.hk/rthk/en/component/k2/1504443-20200123.html.

60. Hafezi, P. Iran bans Chinese citizens from entering the country: IRNA. [Online] 2020 [cited 20208 April]; Available from: https://www.reuters.com/article/us-china-health-iran-ban/iran-bans-chinesecitizens-from-entering-the-country-irna-idUSKCN20L1V7.

61. Index, G. The Global Health Security Index. [Online] 2020 [cited 20208 April]; Available from: https://www.ghsindex.org/. 
62. McAleer, M., Prevention is better than the cure: Risk management of COVID-19. 2020, Multidisciplinary Digital Publishing Institute.

63. Wen, M., C.R. Browning, and K.A. Cagney, Poverty, affluence, and income inequality: neighborhood economic structure and its implications for health. Social Science \& Medicine, 2003. 57(5): p. 843860.

64. Baker, D.P., et al., The education effect on population health: a reassessment. Population and Development Review, 2011. 37(2): p. 307-332.

65. Babones, S.J., Income inequality and population health: correlation and causality. Social Science \& Medicine, 2008. 66(7): p. 1614-1626.

66. Hdr.undp.org. Human Development Reports. [Online] 2020 [cited 20208 April]; Available from: http://hdr.undp.org/en/countries.

67. Triantaphyllou, E., Multi-criteria decision making methods, in Multi-criteria decision making methods: A comparative study. 2000, Springer. p. 5-21.

68. Khakee, A., Evaluation and planning: inseparable concepts. Town Planning Review, 1998. 69(4): p. 359.

69. Lu, H., C.W. Stratton, and Y.W. Tang, Outbreak of Pneumonia of Unknown Etiology in Wuhan China: the Mystery and the Miracle. Journal of Medical Virology, 2020.

70. Xie, B., et al., Global health crises are also information crises: A call to action. Journal of the Association for Information Science and Technology, 2020.

71. Greene, C.J., et al., Coronavirus disease 2019: International public health considerations. Journal of the American College of Emergency Physicians Open, 2020.

72. Allam, Z. and D.S. Jones. On the coronavirus (COVID-19) outbreak and the smart city network: universal data sharing standards coupled with artificial intelligence (Al) to benefit urban health monitoring and management. in Healthcare. 2020. Multidisciplinary Digital Publishing Institute.

73. Smith, G.D., F. Ng, and W. Ho Cheung Li, COVID-19: Emerging compassion, courage and resilience in the face of misinformation and adversity. Journal of Clinical Nursing, 2020.

74. Fernandes, N., Economic effects of coronavirus outbreak (COVID-19) on the world economy. Available at SSRN 3557504, 2020.

75. Organization, W.H., 2019 Novel Corornavirus (2019-nCoV): strategic preparedness and response plan. 2020.

76. Organization, W.H., Consideration for quarantine of individuals in the context of containment for coronavirus disease (COVID-19). URL:

https://apps.who.int/iris/bitstream/handle/10665/331497/WHO-2019-nCoV-IHR_Quarantine-2020.2eng. pdf [accessed 2020-03-26], 2020.

77. Adiga, A., et al., Evaluating the impact of international airline suspensions on the early global spread of COVID-19. medRxiv, 2020. 
78. Zhong, P., S. Guo, and T. Chen, Correlation between travellers departing from Wuhan before the Spring Festival and subsequent spread of COVID-19 to all provinces in China. Journal of Travel Medicine, 2020.

79. Normile, D., Coronavirus cases have dropped sharply in South Korea. What's the secret to its success. Science, 2020. 17(03).

80. Feuer, W. Italy expands its quarantine to the entire country as coronavirus cases and deaths surge. [Online] 2020 [cited 20201 April]; Available from: https://www.cnbc.com/2020/03/09/italy-extendsits-quarantine-to-the-entire-country-pm-asks-residents-to-stay-at-home.html.

81. Barron, L. What We Can Learn From Singapore, Taiwan and Hong Kong About Handling Coronavirus. [Online] 2020 [cited 20208 April]; Available from: https://time.com/5802293/coronavirus-covid19singapore-hong-kong-taiwan/.

82. News.rthk.hk. Visitor Becomes First To Be Quarantined Over Virus. [Online] 2020[cited 20201 April]; Available from: https://news.rthk.hk/rthk/en/component/k2/1504443-20200123.html.

83. Zhuang, Z., et al., Preliminary estimation of the novel coronavirus disease (COVID-19) cases in Iran: a modelling analysis based on overseas cases and air travel data. International Journal of Infectious Diseases, 2020.

84. Tuite, A.R., et al., Estimation of COVID-2019 burden and potential for international dissemination of infection from Iran. medRxiv, 2020.

85. Ghaffarzadegan, N. and H. Rahmandad, Simulation-based Estimation of the Spread of COVID-19 in Iran. medRxiv, 2020.

86. Omi, S., 2006. SARS: how a global epidemic was stopped? Geneva Switzerland: WHO.

87. Syed, A.M., L. Hjarnoea, R. Krumkampc, R. Reintjesc, D. and A.R. Aro. 2016. Developing policy options for SARS and SARS-like diseases a Delphi study. Global Public Health, Vol. 5, No. 6, November 2010, 663_675

88. The Lancet Infectious Diseases, 2004. Reflections on SARS. The Lancet Infectious Diseases, 4(11), 651.

89. Kim, S. and S. Kim. 2018. Exploring the Determinants of Perceived Risk of Middle East Respiratory Syndrome (MERS) in Korea. Int. J. Environ. Res. Public Health 2018, 15, 1168; doi:10.3390/ijerph15061168.

90. Glasser, J.W., Hupert, N., McCauley, MM., and R. Hatchett. 2011. Modeling and public health emergency responses: Lessons from SARS. Epidemics, 3:32-37.

91. Yang, S. and S. Cho. 2017. Middle East respiratory syndrome risk perception among students at a university in South Korea, 2015. Am. J. Infect. Control, 45, e53-e60.

92. Feng, Z., Yang, Y., Xu, D., Zhang, P., McCauley, M.M., Glasser, J.W., 2009. Timely identification of control strategies for emerging infectious diseases. J. Theor. Biol. 259, 165-171.

93. Pan, S. L., Pan, G., and Devadoss, P. R. 2005. E-Government Capabilities and Crisis Management: Lessons from Combating SARS in Singapore. MIS Quarterly Executive. 4, (4), 385-397. Available at: 
https://ink.library.smu.edu.sg/soa_research/627.

94. Covello, V. T., von Winterfeldt, D., \& Slovic, P. (1986). Risk communication: An assessment of the literature on communicating information about health, safety, and environmental risks. Los Angeles, CA: Institute of Safety and Systems Management, University of Southern California.

95. Emanuel, E. E. 2003. The Lessons of SARS. Ann Intern Med. Vol. 139, No. 7: 589-591.

\section{Figures}

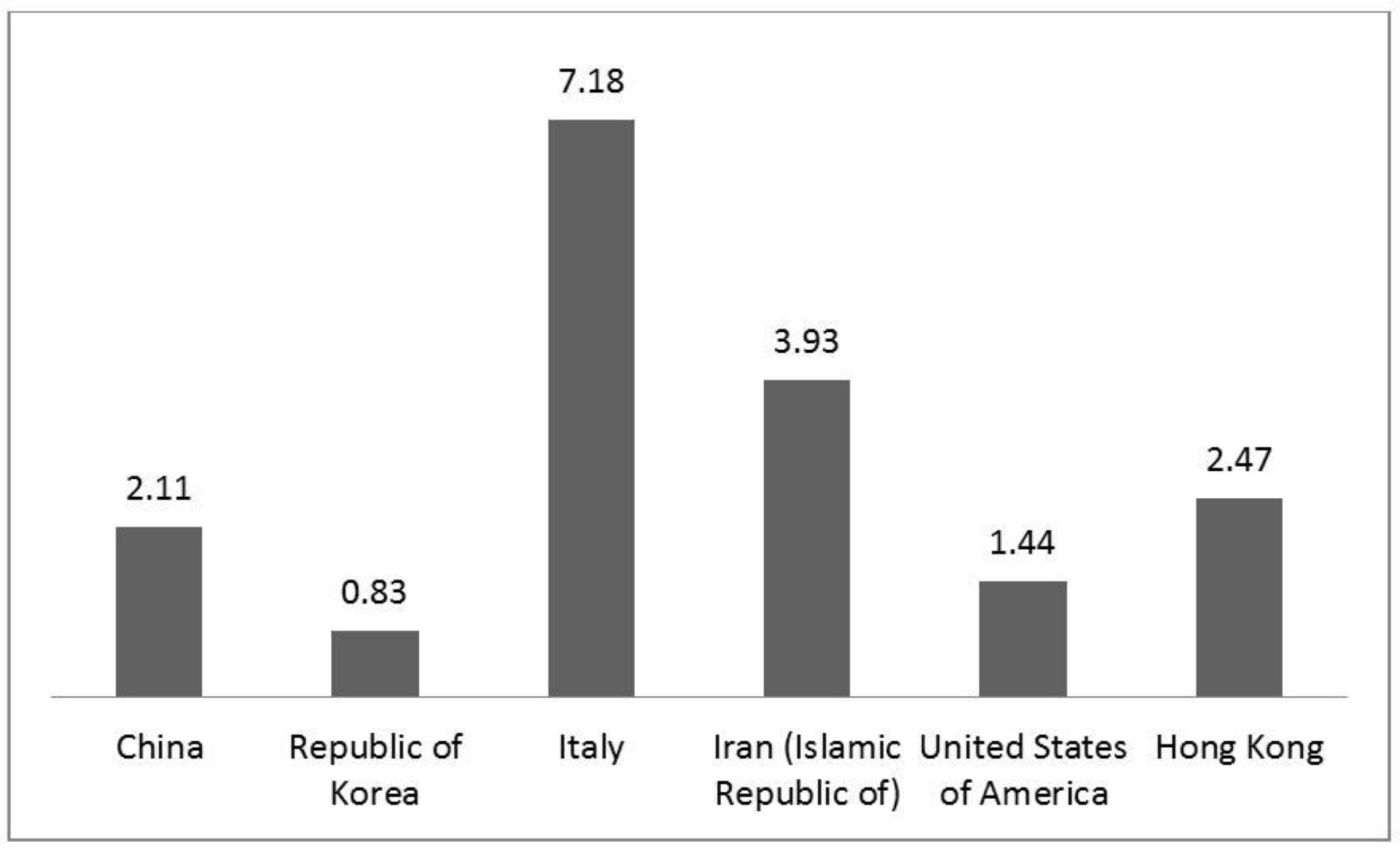

Figure 1

Proportion of mortality to the number of confirmed cases in the first three weeks after the first death in each country 


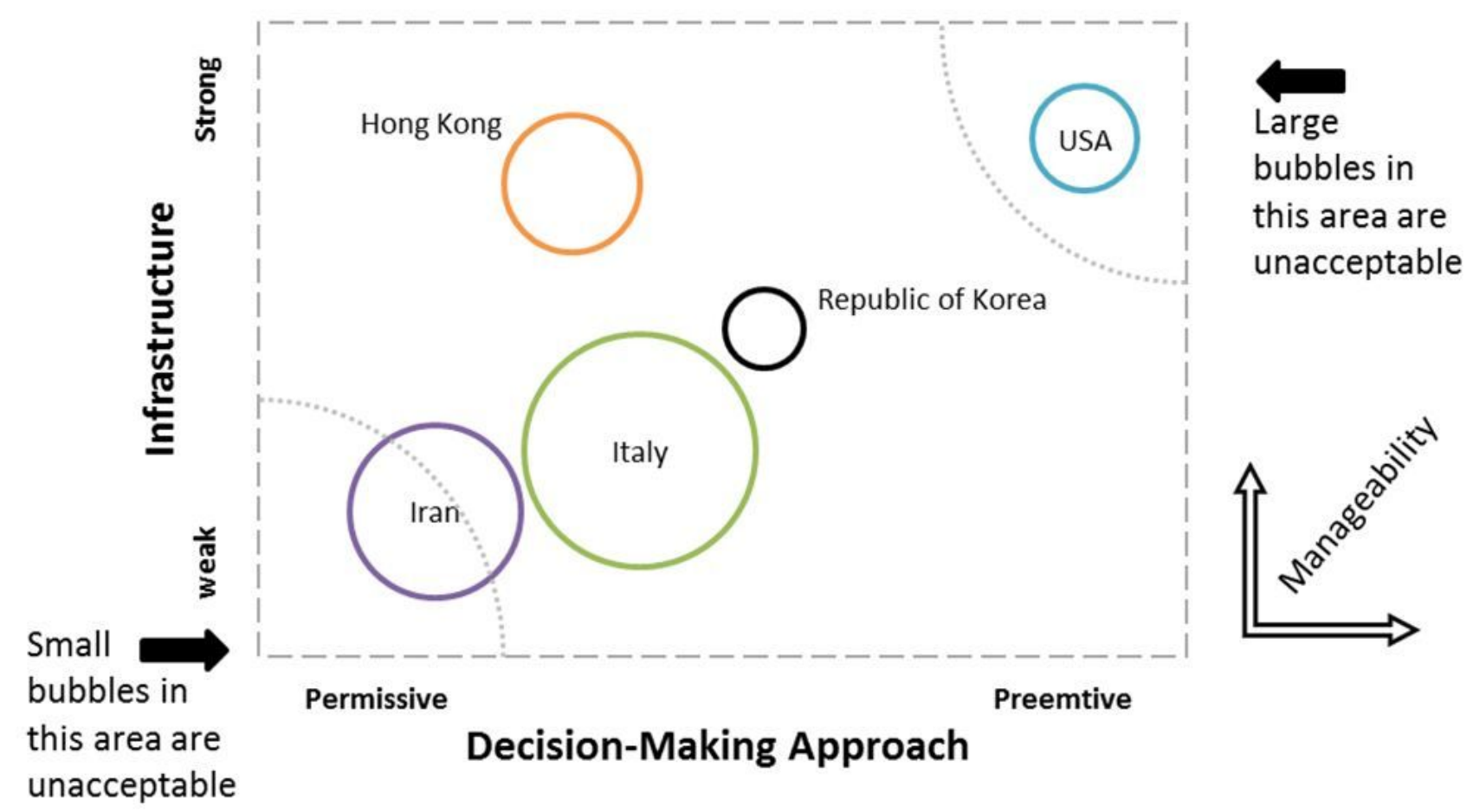

Figure 2

Bubble chart showing the rate of morality relative to time of decision and infrastructures 